\title{
"Relationship between adopting servant leadership style and employee commitment: Empirical evidence from Jordanian governmental hospitals"
}

\begin{tabular}{ll} 
AUTHORS & $\begin{array}{l}\text { Atef Raoush (iD } \\
\text { R }\end{array}$ \\
\hline ARTICLE INFO & $\begin{array}{l}\text { Atef Raoush (2022). Relationship between adopting servant leadership style and } \\
\text { employee commitment: Empirical evidence from Jordanian governmental } \\
\text { hospitals. Problems and Perspectives in Management, 20(1), 299-309. } \\
\text { doi:10.21511/ppm.20(1).2022.25 }\end{array}$ \\
\hline DOI & http://dx.doi.org/10.21511/ppm.20(1).2022.25 \\
\hline RELEASED ON & Tuesday, 22 February 2022 \\
\hline RECEIVED ON & Wednesday, 05 January 2022 \\
\hline ACCEPTED ON & Friday, 11 February 2022 \\
\hline LICENSE & $\begin{array}{l}(c \mathrm{c}) \text { EY } \\
\text { This work is licensed under a Creative Commons Attribution } 4.0 \text { International }\end{array}$ \\
\hline JOURNAL & License \\
\hline ISSN PRINT & "Problems and Perspectives in Management" \\
\hline ISSN ONLINE & $1727-7051$ \\
\hline PUBLISHER & $1810-5467$ \\
\hline FOUNDER & LLC “Consulting Publishing Company “Business Perspectives" \\
\hline
\end{tabular}

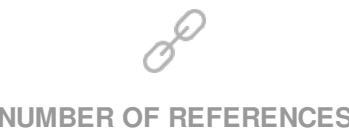

65

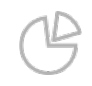

NUMBER OF FIGURES

0
NUMBER OF TABLES

4

(C) The author(s) 2022. This publication is an open access article. 


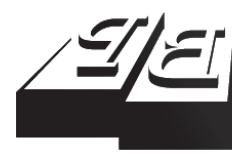

\section{BUSINESS PERSPECTIVES}

LLC "CPC "Business Perspectives" Hryhorii Skovoroda lane, 10, Sumy, 40022, Ukraine www.businessperspectives.org
Received on: $5^{\text {th }}$ of January, 2022 Accepted on: $11^{\text {th }}$ of February, 2022 Published on: 22 $2^{\text {nd }}$ of February, 2022

(C) Atef Raoush, 2022

Atef Raoush, Ph.D., Assistant Professor, Hospital Management Department, Faculty of Business, Philadelphia University, Jordan.

Atef Raoush (Jordan)

RELATIONSHIP BETWEEN

ADOPTING SERVANT LEADERSHIP STYLE AND EMPLOYEE COMMITMENT: EMPIRICAL EVIDENCE FROM JORDANIAN GOVERNMENTAL HOSPITALS

\begin{abstract}
Businesses face a constant struggle in developing leaders who are devoted to serving and developing their people. Therefore, recognizing the link between servant leadership and employee commitment can help organizations establish a more positive working environment, leading to improved employee and organizational performance. This study aims to investigate the relationship between adopting servant leadership by hospital managers and employee commitment within Jordanian governmental hospitals. This paper employs a cross-sectional study design including a quantitative data collection method. Using a simple random sampling method, data were collected from 389 hospital staff employed by Jordanian governmental hospitals. The data were analyzed using Pearson ( $\mathrm{r}$ ) correlation coefficient with hypothesis testing. Research findings revealed a significant positive relationship between the adoption of a servant leadership style by government hospital managers and employee commitment $(r=0.633$, Sig. < 0.01 ). Furthermore, the study showed that demographic variables including gender, age, education, and experience were not associated significantly with employee commitment. The study's results can help hospital managers develop and practice servant leadership, who are expected to increase employee commitment and achieve organizational objectives.
\end{abstract}

\section{Keywords}

JEL Classification

\section{INTRODUCTION}

Leadership is a vital part of the healthcare industry. It is no longer acceptable for medical professionals to neglect the need for good leadership in today's health environment. Healthcare leaders are no longer modest business owners but heads of highly skilled teams of specialists and essential personnel responsible for providing the best possible care and outcomes for patients (Smith, 2019). Several leadership theories improve understanding of leadership as individuals seek to understand what makes a strong leader (Northouse, 2016). Academics have promoted servant leadership as a superior method of leading businesses and individuals. It focuses on inspiring people to achieve corporate goals by making them feel better about their work and keeping them optimistic about their prospects (Song et al., 2015).

The literature on adopting servant leadership style is vague and lacks definition (Eva et al., 2019), and received little empirical examination (Song et al., 2015). This correlational analysis aims to investigate the link between healthcare managers adopting servant leadership and 
employee commitment. This study is essential since it provides new information regarding servant leadership in Jordan's healthcare system. Recognizing the link between adopting servant leadership and subordinates' commitment can aid organizations and employees in establishing a more positive work environment and incorporating it into corporate culture, which could lead to improved employee and organizational performance. It is expected that leaders will emerge with a better knowledge of servant leadership and employee commitment, which will motivate leaders in the studied region to adopt this leadership style to enhance employee work satisfaction, resulting in higher employee engagement. In addition, the paper sought to examine the association between servant leadership and employee commitment in the healthcare sector, particularly within governmental hospitals. The findings will help organizational leaders adopt servant leadership. Furthermore, this study provides hospital managers and healthcare practitioners with information about how employees perceive the leadership styles in their workplace.

\section{LITERATURE REVIEW AND HYPOTHESES}

Leaders of today must excel in ways that their predecessors did not. Leaders in the twenty-first century must be analytical and creative in their thinking, as they are effectively rewriting the concept of leadership (Marques, 2015). A company's competitive advantage comes from having skilled and talented leaders. Businesses invest billions of dollars in leadership development, hoping to get a return on their investment by having leaders who can articulate a compelling vision, lead with integrity, display authenticity, and ethically inspire followers (Salas et al., 2012). Therefore, it is vital to analyze the organization's executives and the leadership styles they deploy to comprehend its performance. As a result, several scholars have sought to define leadership.

Mancha and Yoder (2015) described leadership as a leader's ability to urge organizational members to pursue organizational goals confidently. It is also defined as the process by which leaders utilize their power to persuade and direct employees to willingly contribute to the attainment of shared organizational goals under particular conditions (Yao \& Huang, 2018). Influential leaders provide a clear vision for an organization and boost morale through empowering, encouraging, coaching, and guiding individuals through specific work processes (Gordon, 2017). It is the umbrella word for incorporating ethical and moral considerations into leadership, which has not been fully defined (Karatepe et al., 2019).

As technology advances and more businesses grow into the ever-changing and highly complicated in- ternationalization and globalized markets, leadership research has become a well-known scholarly and professional activity (Gandolfi \& Stone, 2018). Several studies have analyzed alternative leadership methods and their effectiveness in addressing various workplace difficulties. In addition, there have also been many publications in the last ten years that have helped clarify and substantiate servant leadership's fundamental principles (Northouse, 2016).

Robert Greenleaf's 1970 essay "The Servant as Leader" was the earliest mention of the concept of servant leadership in an institutional environment (Parris \& Peachey, 2013). Greenleaf (1970) described servant leadership as a style of life and a management method that is distinct from others because leaders who adopt that leadership style are driven by a natural aspiration to put others' needs ahead of one's own. He stated that servant leaders place a higher value on serving others than on achieving job goals (Song et al., 2015). Moreover, servant leaders highlight the necessities of others and make it a top priority to meet those needs (Muthia \& Krishnan, 2015). A primary interest of servant leaders is the development of others, which enhances employee empowerment and increases institutional performance (Parris \& Peachey, 2013). De Waal and Sivro (2012) described servant leadership as a philosophy in which a person develops a natural desire to serve people by focusing on the well-being of the followers and then assumes the role of leadership to achieve the service to others. It is unquestionably a theory founded on values, trust, and the development of a thoughtful and pioneering leadership culture (Ally, 2019). 
Since being ethical is one of the main features of servant leadership, a thorough understanding of the way servant leadership affects the service atmosphere is an area that warrants additional investigation; it has the ability to benefit both individual employees and the business (Mbandi, 2020). Most scholars on the subject of servant leadership agree on ten essential qualities. These include paying attention, sympathy, healing, mindfulness, influence, conceptualization, forethought, stewardship, commitment, and community building (Denning, 2016). Likewise, Coetzer et al. (2017) listed authenticity, humility, empathy, responsibility, courage, humanity, integrity, and listening as essential attributes of an effective servant leader. Franco and Antunes (2020) identified nine aspects of servant leadership - authorizing, assisting subordinates to develop and succeed, placing employees first, moral actions, understanding or vision, and family environment. As all of these are fundamental elements of servant leadership, and because organizations strive to remain successful, today's organizations might benefit significantly from this study, which looked into how to implement servant leadership in organizations effectively.

Leaders in healthcare organizations must be involved in the way organizations gather and examine outcome data to affect medical professionals' abilities, including performance evaluations in terms of results (Saeed et al., 2015). Since servant leadership is centered on serving others, it is easy to misunderstand the concept and what it implies (Gandolfi et al., 2017). Servant leaders are supposed to manage the business on behalf of a larger group or entity, such as the followers, community, shareholders, or society, focusing on collaboration rather than patriarchal or self-interest (Van Dierendonck \& Patterson, 2015). A servant leader values and respects others' abilities and contributions and is eager to learn from them while also acknowledging their particular strengths and areas for improvement (Coetzer et al., 2017).

Servant leaders may prioritize the necessities of each of their subordinates above their own. As a result, a servant leader impacts followers' relationships, group performance, and employee commitment (Luu, 2019). Therefore, employers prefer versatile and prepared individuals to go above and beyond in the office by engaging in behaviors other than expected in their job descriptions. Servant leaders work hard to build genuine and deep relationships with their subordinates, as well as respond to and support them (Maharaj, 2015). The character of a servant leader must be one of trust and high ethical standards. Servant leaders empower their subordinates (Aij \& Rapsaniotis, 2017). Employees may become overly reliant on a servant leader at times, making it difficult for them to fulfill organizational goals (Palumbo, 2016). However, because a strong emphasis is placed on customer service quality, and employees are driven to go above and beyond to fulfill customers' expectations, it is still a valued leadership style (SavageAustin \& Honeycutt, 2011). Leadership is critical in how an organization runs because, while job performance is based on people, organizational performance is indisputably linked to the leaders of organizations (Kamali, 2014).

Abraham (2012) concluded that happy employees are more engaged and productive in their workplaces. The helping mentality of a servant leader encourages followers to give more and promotes a favorable and beneficial attitude toward organizations (Bambale, 2014). Although the argument over servant leadership will continue, it is undeniably gaining traction worldwide, with an emphasis on engaging employees, being helpful, and collaborating (Ally, 2019). Employees learn to practice serving ideals such as sharing their knowledge and experience, assisting in the development of other colleagues, and engaging in activities that are not required by job descriptions but contribute to the organization by witnessing and learning from servant leaders (Tuan, 2016). Furthermore, subordinates perceived a substantially better degree of job satisfaction when they work for a company dedicated to developing servant leadership characteristics (Kiker et al., 2019).

As a result of adopting a servant leadership style, employees acquire favorable work attitudes. Among the previously mentioned work attitudes, Van Dierendonck (2011) proposed an employee commitment model. While the study primarily applied this commitment to the organization's senior management, it was emphasized that followers might mimic the leader's conduct in their communication with that leader. By providing 
role models, vital guidance, and coaching, employees can learn more about servant leadership's "service" traits, allowing them to become more service-oriented (Greenleaf, 1977).

Irving and Berndt (2017) emphasized the connection between servant leadership and employee satisfaction, leading to improved organizational performance, change management, and other outcomes. Employee satisfaction is positively impacted by a leader who promotes servant leadership (McNeff \& Irving, 2017). According to Liu and Shi (2018), servant leadership is linked to a healthy service climate within organizations of all kinds. Mertel and Brill (2015) also revealed that servant leadership significantly correlates to service climate and citizenship behavior. Empirical research supports and demonstrates the considerable and positive impact of servant leadership on work satisfaction (Majd, 2018). Northouse (2016) went on to say that in order for a servant leader to be efficient, followers must be open to the servant leader's attempts to empower and assist them grow. Song et al. (2015) tried to determine whether servant leadership influences knowledge sharing. The study employed a quantitative method to assess two major parameters: knowledge sharing and team performance. It was discovered that adopting servant leadership had a significant impact on a team's knowledge sharing, resulting in increased overall team productivity and the conceptual framework used to support research.

Furthermore, according to Van Winkle et al. (2014), employee empowerment increases as the supervisor's servant leadership conduct improves. Employees are empowered by direct managers who demonstrate servant leadership by providing knowledge, resources, backing, and authority to perform as desired. The results demonstrated a link between supervisory servant leadership and employee views of follower empowerment. In addition, the findings showed a clear connection between servant leadership and employee performance. Finally, Mathieu et al. (2016) investigated servant and subordinate commitment and work satisfaction using a turnover model. The structural turnover intention model looked at the impact of a supervisor's leadership behavior on employee work satisfaction and commitment.
Moreover, Coetzer et al. (2017) showed that among the most significant characteristics of servant leadership is the significant impact on workers, teams, and organizations. Furthermore, Sokoll (2014) investigated the link between servant leadership and employee commitment to direct managers. The findings revealed that the two factors have a good relationship. However, according to Sokoll (2014), it is critical to find out the correlation between servant leadership and subordinate commitment through empirical research in other organizational settings.

The aim of this study is to investigate the link between healthcare managers adopting a servant leadership style and employee commitment. In addition, the paper is likely to help in advancing the knowledge about whether servant leadership was an ideal leadership style of management or not. Based on the above, the following hypotheses are proposed:

H1: There is a statistically significant relationship between adopting servant leadership by hospital managers in Jordanian governmental hospitals and employee commitment at $p$ $\leq 0.05$.

H2: There is a statistically significant relationship between participants' general characteristics and employee commitment at $p \leq 0.05$.

\section{METHODOLOGY}

The goal of this quantitative correlation study was to find out how servant leadership affects employee commitment using a correlational research design. The focus was to ascertain a link between adopting a servant leadership style and employee commitment. In addition, the paper determined the effect of general characteristics of participants on employee commitment.

The Jordanian Ministry of Health (JMOH) owns and operates 32 hospitals with a percentage of $27.3 \%$ of the total hospitals in Jordan, including 5,251 hospital beds accounting for $35.0 \%$ of total hospital beds in Jordan total of 16,526 governmental hospital workers (JMOH, 2020). The participants were chosen from Jordanian gov- 
ernmental hospital workers; thus, anyone who did not match these requirements was ruled out. A random sample of 490 surveys was delivered to governmental hospitals in Jordan; initially, 490 questionnaires were distributed, but only 389 questionnaires were returned (a response rate of $79.4 \%$ ). Nevertheless, the sample size was sufficient to represent the study population (Sekaran \& Bougie, 2016).

The study questionnaire was developed using servant leadership as an independent variable and employee commitment as a dependent variable. The study's aim, the request for volunteers' input, the importance of responding truthfully, and the measures prepared to protect participants' identity and the acquired data privacy were all explained in the questionnaire's introductory section. The survey was divided into two parts. The first portion collected information about the participants' baseline characteristics, such as age and years of work experience. The following section collected information about the relationship between servant leadership and employee commitment. The items on the questionnaire were rated on a fivepoint Likert scale: Strongly Agree (5), Agree (4), Neutral (3), Disagree (2), and Strongly Disagree (1). Academics from several Jordanian universities and healthcare managers reviewed the questionnaire to ensure its validity, clarity, and lack of ambiguity. The final version of the questionnaire took all of the changes into account. The first 15 items were related to servant leadership and adjusted from Fields and Winston (2012) and Barbuto and Wheeler (2006). In addition, questions 16 to 29 were selected to evaluate employee commitment. Those were developed and modified from Spector and Fox (2011), Podsakoff et al. (1997), and Becker et al. (1996).

To protect the participants and comply with ethical issues during the study, the questionnaire and information on consent and how to participate were distributed to potential volunteers from Jordanian governmental hospitals. Since participation was anonymous, participants were asked not to include any identifying information. In addition, the study took no actions that may be interpreted as supporting or encouraging any unethical activity, such as breaching survey respondent confidentiality, misrepresenting study results, misleading respondents, or avoiding legal liability.

The SPSS software $25^{\text {th }}$ version was utilized to analyze the quantitative data collected from the instruments utilized in this study. First, the study data were subjected to a reliability examination prior to data analysis. The analysis showed an alpha of 0.947 , the result of alpha for each dimension of the questionnaire presented in Table 1. Alpha interpreted as confidence acceptable values for the alpha coefficient are 0.7 and above (LoBiondo-Wood \& Haber, 2013). Therefore, the result of Cronbach's alpha was acceptable for the study tool. Then, the Pearson $r$ method was used to analyze and measure the linear relationship between the independent variable (adopting servant leadership style) and a dependent variable (employee commitment). The significance value was determined at $p<$ 0.05 . Pearson's correlation coefficient is the most well-known and extensively used method for determining correlations among variables (Bernardelli, 2018). The generally used correlation coefficient ( $r$ ) less than 0.3 means weak correlation, equal or above 0.3 and less than 0.5 - moderate correlation, and equal or above 0.5 strong correlation (Heale \& Twycross, 2015).

Table 1. Reliability statistics

\begin{tabular}{l|c:c}
\hline \multicolumn{1}{c|}{ Variables } & $\begin{array}{c}\text { No. of } \\
\text { Items }\end{array}$ & $\begin{array}{c}\text { Cronbach's } \\
\text { Alpha }\end{array}$ \\
\hline $\begin{array}{l}\text { Independent Variable: Servant } \\
\text { leadership items }\end{array}$ & 15 & 0.902 \\
\hdashline $\begin{array}{l}\text { Dependent Variable: Employee } \\
\text { commitment items }\end{array}$ & 14 & 0.941 \\
$\begin{array}{l}\text { Total Questionnaire Cronbach's } \\
\text { Alpha }\end{array}$ & 29 & 0.947 \\
\hline
\end{tabular}

\section{RESULTS}

The paper was dedicated to examining the adoption of servant leadership style by hospital managers in Jordanian governmental hospitals and the impact on employee commitment. Descriptive statistics for the study include frequency and percentage calculated for demographic data. As shown in Table 2, most of the respondents were females (52.2\%), and $47.8 \%$ were males. The majority of responders (45.0\%) were between 35 and 
49 years old, with $12.6 \%$ aged 50 and up. The education level of participants ranged from diploma (29.0\%), bachelor (61.2\%), and the lowest percentage $(9.8 \%)$ was among participants with higher education. $38.3 \%$ of respondents had 3 to 6 years of work experience, while the lowest percentage $(10.5 \%)$ had ten or more years of work experience.

Table 2. Descriptive statistics

\begin{tabular}{|c|c|c|c|}
\hline \multicolumn{2}{|c|}{ Demographics } & \multirow{2}{*}{$\frac{\text { Frequency }}{186}$} & \multirow{2}{*}{$\frac{\text { Percentage }}{47.8 \%}$} \\
\hline Gonder & Male & & \\
\hline Getrae! & Female & 203 & $52.2 \%$ \\
\hline \multirow{3}{*}{ Age } & $\begin{array}{l}20-\text { less than } 35 \\
\text { years }\end{array}$ & 165 & $42.4 \%$ \\
\hline & $\begin{array}{l}35 \text { - less than } 50 \\
\text { years }\end{array}$ & 175 & $45.0 \%$ \\
\hline & $\begin{array}{l}50 \text { years and } \\
\text { above }\end{array}$ & 49 & $12.6 \%$ \\
\hline \multirow{3}{*}{ Education } & Diploma & 113 & $29.0 \%$ \\
\hline & Bachelor & 238 & $61.2 \%$ \\
\hline & $\begin{array}{l}\text { Higher } \\
\text { education }\end{array}$ & 38 & $9.8 \%$ \\
\hline \multirow{4}{*}{$\begin{array}{l}\text { Work } \\
\text { experience }\end{array}$} & $\begin{array}{l}\text { Less than } 3 \\
\text { years }\end{array}$ & 115 & $29.6 \%$ \\
\hline & $\begin{array}{l}3 \text { - less than } 6 \\
\text { years }\end{array}$ & 149 & $38.3 \%$ \\
\hline & $\begin{array}{l}6 \text { - less than } 10 \\
\text { years }\end{array}$ & 84 & $21.6 \%$ \\
\hline & $\begin{array}{l}10 \text { years and } \\
\text { above }\end{array}$ & 41 & $10.5 \%$ \\
\hline
\end{tabular}

In order to test the first hypothesis (H1), Pearson correlation analysis was carried out to investigate the connection between adopting a servant leadership style as an independent variable and employee commitment as a dependent variable. As presented in Table 3, the Pearson correlation coefficient $r$ extracted is positive and significant. Therefore, it means that servant leadership $(0.633$, Sig. $<0.01)$ was associated positively and significantly with employee commitment. Therefore, $\mathrm{H} 1$ is accepted.

Table 3. Pearson correlation

\begin{tabular}{|c|c|c|c|}
\hline \multicolumn{2}{|c|}{ Correlations } & $\begin{array}{c}\text { Servant } \\
\text { Leadership }\end{array}$ & $\begin{array}{c}\text { Employee } \\
\text { Commitment }\end{array}$ \\
\hline \multirow{3}{*}{$\begin{array}{l}\text { Servant } \\
\text { Leadership }\end{array}$} & $\begin{array}{l}\text { Pearson } \\
\text { Correlation }\end{array}$ & 1 & $.633^{* *}$ \\
\hline & $\begin{array}{l}\text { Sig. } \\
\text { (2-tailed) }\end{array}$ & & .000 \\
\hline & N & 389 & 389 \\
\hline \multirow{3}{*}{$\begin{array}{l}\text { Employee } \\
\text { Commitment }\end{array}$} & $\begin{array}{l}\text { Pearson } \\
\text { Correlation }\end{array}$ & $.633^{* *}$ & 1 \\
\hline & $\begin{array}{l}\text { Sig. } \\
\text { (2-tailed) }\end{array}$ & .000 & \\
\hline & $\mathrm{N}$ & 389 & 389 \\
\hline
\end{tabular}

Note: $* *$ means the correlation is significant at the 0.01 level (2-tailed).

To test the second hypothesis (H2), the effect of participants' general characteristics on employee commitment, one-way ANOVA was used. As seen in Table 4, employee commitment was not affected by gender $(p=0.552)$, age $(p=0.102)$, education ( $p$ $=0.158)$, and experience $(p=0.070)$. Therefore, $H 2$ is rejected.

\section{DISCUSSION}

Leaders within the healthcare sector are in high demand for their ability to practice effectively and produce acceptable patient results. In addition, such leaders need to demonstrate to the public that health results are consistent with the latest information and professional knowledge (Saeed et al., 2015). Hence, this study investigated the link between adopting servant leadership style

Table 4. ANOVA test

\begin{tabular}{|c|c|c|c|c|c|c|}
\hline $\begin{array}{c}\text { Participants' general } \\
\text { characteristics }\end{array}$ & Item & Sum of Squares & df & Mean Square & $\mathbf{F}$ & Sig. \\
\hline \multirow{3}{*}{ Gender } & Between Groups & 10.841 & 45 & .241 & .958 & .552 \\
\hline & Within Groups & 86.223 & 343 & .251 & & \\
\hline & Total & 97.064 & 388 & & & \\
\hline \multirow{3}{*}{ Age } & Between Groups & 26.177 & 45 & .582 & 1.302 & .102 \\
\hline & Within Groups & 153.232 & 343 & .447 & & \\
\hline & Total & 179.409 & 388 & & & \\
\hline \multirow{3}{*}{ Education } & Between Groups & 18.973 & 45 & .422 & 1.230 & .158 \\
\hline & Within Groups & 117.567 & 343 & .343 & & \\
\hline & Total & 136.540 & 388 & & & \\
\hline \multirow{2}{*}{ Experience } & Between Groups & 53.896 & 45 & 1.198 & 1.358 & .070 \\
\hline & Within Groups & 302.418 & 343 & .882 & & \\
\hline \multicolumn{2}{|l|}{ Total } & 356.314 & 388 & & & \\
\hline
\end{tabular}


and employee commitment within governmental hospitals in Jordan. Quantitative data were collected from the instruments utilized in this study. Pearson correlation coefficient (r) was calculated; the results revealed that using servant leadership style by hospital managers has a strong correlation with employee commitment in Jordan's government hospitals.

Leadership plays a vital role in all organizations, including health care institutions (Por Pan et al., 2020). Empirical study has shown a significant relationship between adopting a servant leadership style on workers, teams, and organizations. Specifically, servant leadership has been favorably linked to a variety of person, group, and institutional outcomes (Coetzer et al., 2017).

The study's results revealed that hospital managers who practice servant leadership improve employee commitment, which improves hospital performance in the long run. As a result, government hospitals should emphasize the necessity of employing the servant leadership style to improve healthcare services effectively. The study was noteworthy because it demonstrated how servant leadership influences employee commitment. As a result, organizations must prioritize people more than ever before to be effective and profitable (Kiker et al., 2019).
These findings aligned with Coetzer et al. (2017), who supported that servant leadership has a favorable impact on people, teams, and organizations, resulting in increased overall productivity. Similarly, McNeff and Irving (2017) discovered that servant leadership approaches have a solid link to employee commitment. A leader who practices servant leadership positively adds to employee work satisfaction and commitment. In addition, there is also a strong connection between adopting servant leadership and hospital employees' conduct, according to Mertel and Brill (2015) and Panaccio et al. (2015). Furthermore, employees whom servant leaders support are more likely to remain engaged and perform effectively, according to Rui et al. (2017).

On the other hand, Chiniara and Bentein (2016) investigated a link between using servant leadership and employee performance. Their findings indicated a positive correlation, and it is consistent with the result of this study. Eva et al. (2021) found that servant leadership has a more significant influence on subordinates' job satisfaction and commitment to the organization. The study's findings are likely to contribute to a better knowledge of servant leadership, which will motivate leaders in the health care settings to adopt this leadership style, resulting in higher employee engagement.

\section{CONCLUSION}

This paper examines the relationship between servant leadership and hospital employee commitment in Jordan. Using a quantitative research approach, the study concludes that employee commitment is enhanced through adopting servant leadership in governmental hospitals in Jordan. Consequently, a servant leadership style can help healthcare organizations achieve competitive advantages through higher employee engagement. Therefore, it is vital to have hospital leaders who utilize their power to persuade and direct employees to attain shared organizational goals through empowering and encouraging. The findings will contribute to a better understanding of how organizational leaders might use servant leadership, which can aid organizations and employees in establishing a more positive work environment. In addition, future scholars and healthcare practitioners will benefit from the findings of this study in initiating and maintaining training to build servant leadership traits among leaders.

\section{AUTHOR CONTRIBUTIONS}

Conceptualization: Atef Raoush.

Data curation: Atef Raoush.

Formal analysis: Atef Raoush.

Funding acquisition: Atef Raoush. 
Investigation: Atef Raoush.

Methodology: Atef Raoush.

Project administration: Atef Raoush.

Resources: Atef Raoush.

Supervision: Atef Raoush.

Validation: Atef Raoush.

Writing - original draft: Atef Raoush.

Writing - review \& editing: Atef Raoush.

\section{ACKNOWLEDGMENT}

The publication of this study has been supported by the Deanship of Scientific Research and Graduate Studies at Philadelphia University - Jordan.

\section{REFERENCES}

1. Abraham, S. (2012). Development of employee engagement programme on the basis of employee satisfaction survey. Journal of Economic Development, Management, IT, Finance, and Marketing, 4(1), 27-37. Retrieved from https://www.researchgate. net/publication/256187156_Development_of_Employee_Engagement_Programme_on_the_basis_of_Employee_Satisfaction

2. Aij, K. H., \& Rapsaniotis, S. (2017). Leadership requirements for lean versus servant leadership in health care: A systematic review of the literature. Journal of Healthcare Leadership, 9, 1-14. https://doi. org/10.2147/JHL.S120166

3. Ally, S. A. (2019). Servant Leadership Principles, Practices And Ethics. Retrieved November 4, 2021, from http://www. guyanaembassy-kuwait.com/pdf/ ALLY-2013-SERVANT\%20LEADERSHIP\%20PINCIPLES\%20 PRACTICES\%20AND\%20ETHICS-8-29-13.pdf

4. Bambale, A. (2014). Relationship between servant leadership and organizational citizenship behaviors: review of literature and future research directions. Journal of Marketing \& Management, 5(1), 1-16. Retrieved from https:// www.semanticscholar.org/paper/ Relationship-between-ServantLeadership-and-Review-Bambale/ afea728327c868da1614b65af4ef76 95b31b412c\#references
5. Barbuto, J., \& Wheeler, W. (2006). Scale development and construct clarification of servant leadership. Group and Organization Management, 31(3), 300-326. Retrieved from https://digitalcommons.unl.edu/cgi/viewcontent.cg i article $=1050 \&$ context $=$ aglecfa cpub

6. Becker, T., Billings, R., Eveleth, D., \& Gilbert, N. L. (1996). Foci and bases of employee commitment: Implications for job performance. Academy of Management Journal, 39(2), 464-482.

7. Bernardelli, M. (2018). Hidden Markov models as a tool for the assessment of dependence of phenomena of economic nature. Acta Universitatis Lodziensis. Folia Oeconomica, 5(338), 7-20. Retrieved from http://bazekon. icm.edu.pl/bazekon/element/ bwmeta1.element.ekon-element-000171534163

8. Chiniara, M., \& Bentein, K. (2016). Linking Servant Leadership to Individual Performance: Differentiating the Mediating Role of Autonomy, Competence and Relatedness Need Satisfaction. The Leadership Quarterly, 27(1), 124-141. https://doi.org/10.1016/j. leaqua.2015.08.004

9. Coetzer, M. F., Bussin, M. H., \& Geldenhuys, M. (2017). Servant leadership and work- related wellbeing in a construction company. South African Journal of Industrial
Psychology, 43, 282-291. https:// doi.org/10.4102/sajip.v43i0.1478

10. De Waal, A., \& Sivro, M. (2012) The relationship between servant leadership, organizational performance, and the highperformance organization framework. Journal of Leadership \& Organizational Studies, 19(2), 173-190. https://doi. org/10.1177/1548051812439892

11. Denning, S. (2016). Agile's ten implementation challenges. Strategy \& Leadership, 44(5), 15 20. https://doi.org/10.1108/SL-082016-0065

12. Eva, N., Robin, M., Sendjaya, S., Dierendonck, D., \& Liden, R. C. (2019). Servant leadership: a systematic review and call for future research. The Leadership Quarterly, 30(1), 111-132. https://doi.org/10.1016/j. leaqua.2018.07.004

13. Eva, N., Sendjaya, S., Prajogo, D., \& Madison, K. (2021).

Does organizational structure render leadership unnecessary? Configurations of formalization and centralization as a substitute and neutralizer of servant leadership. Journal of Business Research, 129, 43-56. https://doi. org/10.1016/j.jbusres.2021.02.023

14. Fields, D. L., \& Winston, B. E. (2012). Seeking the essence of servant leadership. Regent University. 
15. Franco, M., \& Antunes, A. (2020). Understanding servant leadership dimensions: Theoretical and empirical extensions in the Portuguese context. Nankai Business Review International, 11(3), 345-369. https://doi. org/10.1108/NBRI-08-2019-0038

16. Gandolfi, F., \& Stone, S. (2018). Leadership, leadership styles, and servant leadership. Journal of Management Research, 18(4), 261-269. Retrieved from https:// www.lasnny.org/wp-content/ uploads/2018/11/LeadershipLeadership-Styles-and-ServantLeadership.pdf

17. Gandolfi, F., Stone, S., \& Deno, A (2017). Servant leadership: An ancient style with 21 st century relevance. Revista de Management Comparat International, 18(4), 350- 361. Retrieved from https:// ideas.repec.org/a/rom/rmcimn/ v18y2017i4p350-361.html

18. Gordon, G. (2017). Leadership through trust: Leveraging performance and spanning cultural boundaries. Berlin, Germany: Springer.

19. Greenleaf, R. (1970). The servant as leader. New York, NY: Paulist Press.

20. Greenleaf, R. K. (1977). Servant leadership: A journey into the nature of legitimate power and greatness. New York, NY: Paulist Press.

21. Heale, R., \& Twycross, A (2015). Validity and reliability in quantitative studies. EvidenceBased Nursing, 18(3), 66-67. https://doi.org/10.1136/eb-2015102129

22. Hong, G., Cho, Y., Froese, F., \& Shin, M. (2016). The effect of leadership styles, rank, and seniority on affective organizational commitment: A comparative study of US and Korean employees. Cross Cultural \& Strategic Management, 23(2), 340-362. https://doi.org/10.1108/ CCSM-03-2014-0034

23. Irving, J. A., \& Berndt, J. (2017) Leader purposefulness within servant leadership: Examining the effect of servant leadership, leader follower-focus, leader goal- orientation, and leader purposefulness in a large U.S. healthcare organization. Administrative Sciences, 7(2), 10. https://doi.org/10.3390/admsci7020010

24. Jảafaru, A. (2014). Relationship between servant leadership and organizational citizenship behaviors: Review of literature and future research directions. Journal of Marketing \& Management, 5(1), 1-16.

25. Jones, T. J. (2014). The Role Of A Servant-Leadership-Centered Approach On Preventing Hazing: A Focus On One Historically Black University Marching Band. North Carolina Agricultural and Technical State University. Retrieved November 7, 2021, from https://digital.library.ncat.edu/ dissertations/79

26. Jordanian Ministry of Health (JMOH). (2020). MOH Annual Report. Jordan. Retrieved from https://www.moh.gov.jo/ebv4.0/ root_storage/ar/eb_list_page/\% D8\%A7\%D9\%84\%D8\%AA\%D 9\%82\%D8\%B1\%D9\%8A\%D8\% B1_\%D8\%A7\%D9\%84\%D8\%A 7\%D8\%AD\%D8\%B5\%D8\%A7 \%D8\%A6\%D9\%8A \%D8\%A7 \%D9\%84\%D8\%B3\%D9\%86\%D 9\%88\%D9\%8A_\%D9\%84\%D8 \%B9\%D8\%A7\%D9\%85_2020.pdf

27. Kamali, H. (2014). Studying the relationship between transformational leadership style and gain competitive advantage (Case Study: Wire and Cable Company at Moghan Located in Shahrood City). Reef Resources Assessment and Management Technical Paper, 40(1), 518-532.

28. Karatepe, O., Ozturk, A., \& Kim, T. T. (2019). Servant leadership, organizational trust, and bank employee outcomes. The Service Industries Journal, 39(2), 86-108. https://doi.org/10.1080/02642069. 2018.1464559

29. Kiker, D., Callahan, J., Kiker, M. B., \& Bri, A. (2019). Exploring the boundaries of servant leadership: A meta-analysis of the main and moderating effects of servant leadership on behavioral and affective outcome. Journal of Managerial Issues, 31(2), 172-197.

30. Liu, P., \& Shi, J. (2018).

Transmission of service from leader to followers: A parallel multiple mediator model. Social Behavior and Personality, 46(5), 769-782. https://doi.org/10.2224/ sbp.6653

31. Ljungholm, D. P. (2016). Effective servant leadership behavior in organizations. Linguistic and Philosophical Investigations, 15, 239-245. Retrieved from https:// addletonacademicpublishers.com/ linguistic-and-philosophicalinvestigations

32. LoBiondo-Wood, G., \& Haber, J. (2013). Nursing research in Canada:Methods, critical appraisal and utilization with study guide. Milton, ON: Elsevier Science.

33. Luu, T. T. (2019). Building employees' organizational citizenship behavior for the environment: The role of environmentally specific servant leadership and a moderated mediation mechanism. International Journal of Contemporary Hospitality Management, 31(1), 406-426. Retrieved October 14, 2021, from https://www.emerald.com/ insight/content/doi/10.1108/ IJCHM-07-2017-0425/full/html

34. Maharaj, R. (2015). Servant leadership and its implications for organisational management in the furniture décor industry: A case study. International Journal of Business Management and Economics Research, 2(2), 83-93. Retrieved September 7, 2021, from http://www.irphouse.com/ volume/ijbmerv2n2.htm

35. Majd, M. (2018). Insights on practicing of servant leadership in the events sector. Sport, Business and Management, 8(2), 134-152. https://doi.org/10.1108/SBM-012017-0001

36. Mancha, R. M., \& Yoder, C. Y. (2015). Cultural antecedents of green behavioral intent: An environmental theory of planned behavior. Journal of Environmental Psychology, 43, 145-154. https://doi.org/10.1016/j. jenvp.2015.06.005 
37. Marques, J. (2015). The changed leadership landscape: What matters today. Journal of Management Development, 34(10), 1310-1322. https://doi. org/10.1108/JMD-02-2015-0010

38. Mathieu, C., Fabi, B., Lacoursiere, R., \& Raymond, A. (2016). The role of supervisory behavior, job satisfaction and organizational commitment on employee turnover. Journal of Management and Organization, 22(1), 113129. http://doi.org/10.1017/ jmo.2015.25

39. Mbandi, J. (2020). The Relationship Between Servant Leadership And Organizational Citizenship Behavior, Job Satisfaction, And Service Climate. Trevecca Nazarene University. Retrieved from https://www.proquest.com/openview/23e71c091ec 7e245e3d2a8c54231c5e3/1?pq-ori gsite $=$ gscholar\&cbl $=18750 \&$ diss $=\mathrm{y}$

40. McNeff, M. E., \& Irving, J. A. (2017). Job satisfaction and the priority of valuing people: A case study of servant leadership practice in a network of family-owned companies. Sage Open, 7(7). https://doi. org/10.1177/2158244016686813

41. Mertel, T., \& Brill, C. (2015). What every leader ought to know about becoming a servant leade. Industrial and Commercial Training, 47(5), 228-235. https:// doi.org/10.1108/ICT-02-20150013

42. Mitchel, E. (2019). A Supervisors' Servant Leadership Style and Employee Commitment to a Supervisor. Northcentral University. Retrieved from https:// www.proquest.com/openview/64 d0b4055390d97b52482cdb102178 ea/1.pdf?pq-origsite=gscholar\&cbl $=18750 \&$ diss $=\mathrm{y}$

43. Murari, K., \& Gupta, K. (2012). Impact of servant leadership on employee empowerment. Journal of Strategic Human Resource Management, 1(1), 28-37. Retrieved from http://www.ischolar.in/index.php/jshrm/article/view/38246

44. Muthia, A., \& Krishnan, V. (2015). Servant leadership and commitment: Role of transformational leadership. International Journal on Leadership, 3(1), 9-20. Retrieved from http:// www.publishingindia.com/ijl/60/ servant-leadership-and-commitment-role-of-transformationalleadership/369/2656/

45. Northouse, P. G. (2016) Leadership: Theory and practice ( $^{\text {th }}$ ed.). Los Angeles, CA, US: Sage.

46. Palumbo, R. (2016). Challenging servant leadership in the nonprofit sector: The side effects of servant leadership. Journal of Nonprofit Education and Leadership, 6(2). https://doi.org/10.18666/JNEL2016-V6-I2-6824

47. Panaccio, A., Magda, D., SaintMichel, S., \& Liden, R. C. (2015). Servant leadership and well-being. In R. J. Burke, K. M. Page, \& C. L. Cooper (Eds.), Flourishing in Life, Work and Careers: Individual Wellbeing and Career Experiences.

48. Parris, D. L., \& Peachey, J. W. (2013). A systematic literature review of servant leadership theory in organizational contexts. Journal of Business Ethics, 113(3), 377-393. https://doi.org/10.1007/s10551012-1322-6

49. Podsakoff, P. M., Ahearne, M., \& MacKenzie, S. (1997). Organizational citizenship behavior and the quantity and quality of work group performance. Journal of Applied Psychology, 82(2), 262-270. https://doi. org/10.1037/0021-9010.82.2.262

50. Por Pan, T., Trakulmututa, J., \& Youravong, N. (2020). Selfperception of leadership style of dentists: Heads of dental departments in community hospitals, Southern Thailand. International Dental Journal, 70(3), 193-200. https://doi.org/10.1111/ idj. 12544

51. Rivkin, W., Diestel, S., \& Schmidt, K. (2014). The positive relationship between servant leadership and employees' psychological health: A multi-method approach. German Journal of Human Resource Management, 28(1-2), 52-72. https://doi. org/10.1177/239700221402800104
52. Rui, Y., Ying, M., \& Jianhong, M. (2017). How do servant leaders promote engagement? A bottomup perspective of job crafting. Social Behavior and Personality An International Journal, 45(11), 1815-1828. https://doi.org/10.2224/ sbp. 6704

53. Saeed, A., Bloch, R., \& Silver, S. (2015). Role of leadership in narrowing the gap between science and practice: Improving treatment outcomes at the systems level. Psychiatry Quarterly, 86(3), 311-323.

54. Salas, E., Tannenbaum, S., Kraiger, K., \& Smith, A. (2012). The science of training and development in organizations: What matters in practice. Psychological Science in the Public Interest, 13(2), 74-101. https://doi. org/10.1177/1529100612436661

55. Savage-Austin, A. R., \& Honeycutt, A. (2011). Servant leadership: A phenomenological study of practices, experiences, organizational effectiveness, and barriers. Journal of Business \& Economics Research, 9(1), 49-54. https://doi.org/10.19030/jber. v9i1.939

56. Sekaran, U., \& Bougie, R. (2016) Research Methods for Business: A Skill-Building Approach. Wiley \& Sons Ltd.

57. Smith, R. (2019). Leadership Strategies To Improve Healthcare Outcomes. Pepperdine University. Retrieved from https://www.proquest.com/openview/4832081211c 01092977399e51762ea56/1?pq-ori gsite $=$ gscholar $\& \mathrm{cbl}=18750 \&$ diss $=\mathrm{y}$

58. Sokoll, S. (2014). Servant leadership and employee commitment to a supervisor. International Journal of Leadership Studies, 8(2), 88-104. Retrieved from https://www.regent.edu/ acad/global/publications/ijls/new/ vol8iss2/5-Sokoll.pdf

59. Song, C., Park, K. R., \& Kang, S-W. (2015). Servant leadership and team performance: The mediating role of knowledge-sharing climate. Social Behavior \& Personality. An International Journal, 43(10), 1749-1760. https://doi.org/10.2224/ sbp.2015.43.10.1749 
60. Spector, P. E., \& Fox, S. (2011). Organizational citizenship behavior checklist. Routledge. Retrieved from https://paulspector.com/ assessments/pauls-no-cost-assessments/organizational-citizenshipbehavior-checklist-OCB-C/

61. Tuan, L. T. (2016). How servant leadership nurtures knowledge sharing. International Journal of Public Sector Management, 29(1) 91-108. https://doi.org/10.1108/ IJPSM-06-2015-0112

62. Van Dierendonck, D. (2011). Servant leadership: A review and synthesis. Journal of Management, 37(4), 1228-1261.

https://doi-org.libaccess.sjlibrary. org/10.1177/0149206310380462

63. Van Dierendonck, D., \& Patterson, K. (2015). Compassionate Love as a Cornerstone of Servant Leadership: An Integration of Previous Theorizing and Research. Journal of Business Ethics, 128(1), 119-131. Retrieved from https:// www.jstor.org/stable/24702857

64. Van Winkle, B., Allen, S., DeVore, D., \& Winston, B. (2014). The relationship between the servant leadership behaviors of immediate supervisors and followers' perceptions of being empowered in the context of small business. Journal of Leadership Education, 13(3). http://doi.org/10.12806/V13/ I3/R5

65. Yao, C., \& Huang, P. (2018).

Effects of leadership style on job satisfaction and intention to stay in shipping industry. Journal of Coastal Research, 83(S1), 796-801. 